\title{
First report of a natural helminth infection in the Japanese quail Coturnix japonica Temminck \& Schlegel (Aves, Phasianidae, Galliformes) in the Neotropical region
}

\author{
Roberto M. Pinto ${ }^{1,4}$, Rodrigo C. Menezes ${ }^{2}$, Rogério Tortelly ${ }^{3}$, Dely Noronha ${ }^{1}$ \\ ${ }^{1}$ Laboratório de Helmintos Parasitos de Vertebrados, Departamento de Helmintologia, Instituto Oswaldo Cruz. Avenida \\ Brasil 4365, 21040-900 Rio de Janeiro, Rio de Janeiro, Brasil. \\ 2 Centro de Criação de Animais de Laboratório (CECAL), Fiocruz. \\ ${ }^{3}$ Departamento de Patologia, Faculdade de Veterinária, Universidade Federal Fluminense. Rua Vital Brazil Filho 64, 24230 - \\ 340 Niterói, Rio de Janeiro, Brasil. \\ ${ }^{4}$ Corresponding author: E-mail: rmpinto@ioc.fiocuz.br. CNPq research fellow.
}

\begin{abstract}
The present findings are related to the report of the first natural helminth infection in the Japanese quail, Coturnix japonica Temminck \& Schlegel, 1849 in Brazil. The kidney trematode Tanaisia inopina Freitas, 1951 is referred for the first time in the investigated host.

KEY WORDS. Birds, Brazil, helminths.
\end{abstract}

RESUMO. Primeiro relato de infecção helmíntica natural na codorna-doméstica Coturnix japonica Temminck \& Schlegel (Aves, Phasianidae, Galliformes) na região Neotropical. Os presentes resultados relacionam-se ao primeiro relato de infecção natural por helmintos na codorna doméstica, Coturnix japonica Temminck \& Schlegel, 1849 no Brasil. O trematódeo renal Tanaisia inopina Freitas, 1951 é assinalado pela primeira vez nesta espécie de ave. PALAVRAS CHAVE. Brasil, helmintos.

The domestic or Japanese quail, is of great economic importance considering the commerce of eggs of these birds that have been commonly supplying the Brazilian markets, since they were accepted by the population as a source of proteins.

According to Sick (2001), in Brazil these quails are only maintained in captivity, since efforts to introduce this species in wild environments failed; incubatory weakening and disuse atrophy of the wings were observed. Birds were easily captured by hawks and small carnivores and thus became extinct in the experimental introduction areas.

Birds from backyard flocks are generally either kept in cages or pen-raised; with the latter method, birds can be in contact with the ground and thus, feed on invertebrate hosts that commonly are intermediate hosts for helminths in the case of heteroxenous life cycles. The Japanese quail is frequently used overseas for experimental helminth infections (LUND \& Chute 1974, Movsessian \& Pkhrikian 1994, Maruyama et al. 1994) not always well succeeded (Devada \& Sathianesan 1996); reports of natural infections are few and mostly restricted to the countries in which these birds are found in wild environments (SAWAda \& FunABashi 1972, Wang 1982, Barus \& Sonin 1983, UCHIDA et al. 1984, KumAr et al. 2003), suggesting that either this avian species presents a high refractoriness for both patterns of infection or have been poorly investigated.

Considering this fact, the present data on the occurrence of a trematode species, Tanaisia inopina Freitas, 1951, are related to the first case of a natural helminth infection of the Japanese quail to be reported in the Neotropical region.

\section{MATERIAL AND METHODS}

Ten adult specimens of the Japanese quail, 5 males, 5 females, from backyard flocks of Duque de Caxias $\left(22^{\circ} 47^{\prime} 08^{\prime \prime}\right.$; $\left.43^{\circ} 18^{\prime} 42^{\prime \prime} \mathrm{W}\right)$, State of Rio de Janeiro, Brazil, were investigated for helminths. Specimens were necropsied in accordance with ethical procedures and dissected organs, kept in Petri dishes with a $0.85 \% \mathrm{NaCl}$ solution were examined under a stereoscope microscope. Specimens of trematodes were recovered from one of the kidneys; the other was fixed in $10 \%$ formaldehyde solution and then routinely processed for paraffin embedding. Five micrometers thick sections were stained with hematoxylin and eosin (HE). The two recovered worms were compressed-fixed in cold A.F.A (ethanol $70^{\circ} \mathrm{GL}, 93 \%$; formaldehyde, 5\%; glacial acetic acid, 2\%), stained with alcoholic 


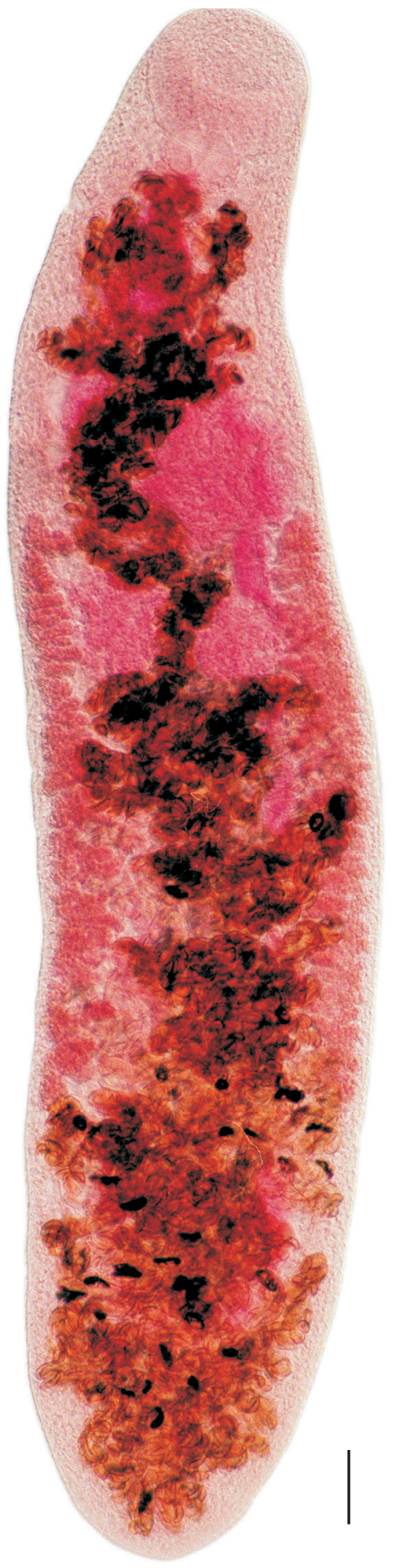

Figure 1. Tanaisia inopina: whole mount. Bar $=0.35 \mathrm{~mm}$.

chlroride Langeron's carmine, dehydrated in an alcoholic series $\left(70^{\circ}-100^{\circ} \mathrm{GL}\right)$, cleared in phenol, and kept as whole mounts in a solution 3:1 of beechwood creosote and Canada balsam, respectively. Specimens were deposited in the Helminthological Collection of the Oswaldo Cruz Institute (CHIOC). Measurements are in millimeters ( $\mathrm{mm}$ ). NHR refers to New Host Record. Photomicrograph was obtained in a Zeiss Axiophot bright-field microscope with a D.I.C (Differential Interference Contrast) system. Classification of the parasites is in accordance with Freitas $(1951,1959)$ and that of the host follows SiCK (2001). The development of this investigation has been authorized by the Committee of Ethics for the Use of Animals (CEUA/Fiocruz) no. P0095-01.

\section{RESULTS}

The prevalence of parasitism was of $10 \%$ and two specimens (one damaged) of the digenean, trematode Tanaisia inopina Freitas, 1951 (Fig. 1), on which a brief description is based, were recovered from one of the kidneys of the infected bird.

Digenea, Eucotylidae. Body flattened, 1.9 long, 0.45 wide. Tegument with scales. Oral sucker 0.17 long, 0.21 wide. Acetabulum not observed. Pharynx 0.05 long, 0.08 wide. Esophagus present. Intestinal ceca anastomosed in the posterior portion. Genital pore close to the cirrus pouch. Testes intercecal, in the same zone or slightly in diagonal, with sinuous or lobed surfaces, 0.15 long, 0.12 wide. Ovary lateral, slightly lobed, intercecal 0.20 in length and 0.15 in width. Vitellaria follicular, almost entirely extracecal. Eggs brownish, 0.035-0.037 in length and 0.017 in width. Excretory pore terminal.

Host. Coturnix japonica Temmink \& Schlegel, 1849, Galliformes, Phasianidae; common names: Japanese quail, "codorna-doméstica" (NHR).

Other hosts. Passer domesticus (Linnaeus, 1758), Passeriformes, Ploceidae; common names: sparrow, "pardal", Sterna sp., Charadriiformes, Laridae and Icterus chrysocephalus (Linnaeus, 1766), Passeriformes, Icteridae; common names: moriche oriole, "rouxinol-do-Rio Negro".

Site of infection: kidneys.

Locality. Duque de Caxias, State of Rio de Janeiro, Brazil.

Deposited studied specimens: CHIOC no. 36496 a-b (whole mounts).

Birds did not show clinical signs. Neither gross nor microscopic lesions due to the presence of $T$. inopina were observed; the species is referred for the first time in the Japanese quail from Brazilian backyard flocks.

\section{DISCUSSION}

Natural infections of helminths in the Japanese quail have been reported overseas, mostly from Asia (China, Japan) (SAWADA \& FunABashi 1972, WANG 1982, UCHIDA et al. 1984), from the Palaearctic region (BARUS \& SONIN 1983) and India (KumAr et al. 2003). The helminth species so far referred are the trematode Pancreatrema coturnicola Wang, 1982, the cestodes Metroliasthes 
coturnix Sawada \& Funabachi, 1972, Choanotaenia infundibulum (Bloch, 1779), Raillietina tetragona (Molin, 1858), and the nematodes Acuaria gruveli, (Gendre, 1913), Cyrnea eurycerca Seurat, 1914, Subulura skrjabini (Semevov, 1926), Strongyloides avium Cram, 1929, Dispharynx nasuta (Rudolphi, 1819), Ascaridia galli (Schrank, 1778) Freeborn, 1923, Heterakis gallinarum (Schrank, 1778) and Capillaria obsignata Madsen, 1945.

The digenetic trematode Tanaisia inopina was previously identified as Tamerlania zarudnyi Skrjabin, 1924 by Almeida (1936), on the basis of specimens recovered from the kidneys of the common sparrow $P$. domesticus, captured in a suburban area of Rio de Janeiro, State of Rio de Janeiro, Brazil. Later, Freitas (1951) restudied samples of this trematode, deposited in the CHIOC and proposed Tanaisia inopina, taking into account that important morphometric data had been overlooked by ALMEIDA (1936). Later, Freitas (1959) referred to T. inopina in Sterna sp. from Rio de Janeiro and Franco (1965) in Icterus chrysocephalus (Linnaeus, 1776) from the State of Amazonas. More recently, Amato \& Brasil (1990) and Brasil \& Aмato (1992) again referred this trematode in $P$. domesticus, the type host of the species, also from Rio de Janeiro, the type locality. Thus, this is another reference of T. inopina in a new but economically important host. As previously discussed by PINTO et al. (2004) the spreading of the avian renal monostomosis due to the presence of Paratanaisia bragai (Santos, 1934) Freitas, 1959 also a kidney trematode, closely related to species of the genus Tanaisia Skrjabin, 1924, in ruddy ground doves, pigeons, chickens, guinea fowls and peacocks, suggests that in the case of $T$. inopina, the dispersion of the species may be related to the gregariousness and to the feeding habits of the sparrows, that are worldwide distributed. According to Brasil \& AMATO (1992), in the yards where sparrows look for food, terrestrial snails, such as Subulina octona Bruguière, 1789, can act as intermediate hosts for T. inopina, since these snails, when feeding on the watery contents of feces of the parasitized birds, are infected by the miracidia of viable eggs that further develop into metacercariae that are ingested by the sparrows together with the contaminated snails.

\section{REFERENCES}

AlmeidA, J.L. 1936. Sobre alguns helmintos ainda não observados no Brasil. Revista do Departamento Nacional de Produção Animal, Rio de Janeiro, 2: 415-416.

Aмato, S.B. \& M.C. Brasil. 1990. Os helmintos do pardal (Passer domesticus Linnaeus, 1758) como reflexo do seu comportamento alimentar. Ciência e Cultura, São Paulo, 42: 520-521.

Barus, V. \& M.D. Sonin. 1983. Survey of nematodes parasitizing the genus Coturnix (Galliformes) in the Palaearctic region. Helminthologia, Kosice, 20: 175-186.

Brasil, M.C. \& S.B. Amato. 1992. Faunistic analysis of the hel- minths of sparrows (Passer domesticus L., 1758) captured in Campo Grande, Rio de Janeiro, RJ. Memórias do Instituto Oswaldo Cruz, Rio de Janeiro, 87 (Suppl. I): 43-48.

Devada, K. \& V. Sathianesan. 1996. Refractoriness of Japanese quails (Coturnix coturnix japonica) to Syngamus trachea (Montagu, 1811) infection. Journal of Veterinary and Animal Sciences, Lahore, 27: 47-48.

Franco, S.R.N.S. 1965. Nota sobre trematódeos eucotilídeos (Trematoda, Eucotylidae). Memórias do Instituto Oswaldo Cruz, Rio de Janeiro, 63: 59-65.

Freitas, J.F.T. 1951. Revisão da família Eucotylidae Skrjabin, 1924 (Trematoda). Memórias do Instituto Oswaldo Cruz, Rio de Janeiro, 49: 33-123.

Freitas, J.F.T. 1959. Nota sobre Tanaisia inopina Freitas, 1951 (Trematoda, Eucotylidae). Atas da Sociedade de Biologia do Rio de Janeiro, Rio de Janeiro, 3: 2-4.

KumAr, R.; S.R.P. SinHA \& M.N. SAHAY. 2003. Seasonal and agewise prevalence of helminthic infection in Japanese quail (Coturnix coturnix japonica) in Patna, Bihar. Indian Journal of Poultry Science, Izatnagar, 38: 32-36.

Lund, E.E. \& A.M. Chute. 1974. Reciprocal transfer of Heterakis gallinarum larvae between ring-necked pheasants and Japanese quail: effects on $H$. gallinarum, Histomonas meleagris and Parahistomonas wenrichi. Proceedings of the Helminthological Society of Washington 41: 73-76.

Maruyama, S.; K. Yamamoto; Y. Katsube. 1994. Infectivity of Toxocara canis larvae from Japanese quails in mice. Journal of Veterinary Medical Science, Tokio, 56: 399-401.

Movsessian, S.O. \& L. V. Pkhrikian. 1994. Reciprocal infection of quails and hens with the nematodes Ascaridia galli (Schrank, 1788) and Heterakis gallinae (Gmelin, 1790): single and mixed infections. Parasitologia Hungarica, Budapest, 27: 83-85.

Pinto, R.M.; R.C. Menezes \& R. Tortelly. 2004. Systematic and pathologic study of Paratanaisia bragai (Santos, 1934) Freitas, 1959 (Digenea, Eucotylidae) infestation in ruddy ground dove Columbina talpacoti (Temminck, 1811). Arquivos Brasileiros de Medicina Veterinária e Zootecnia, Belo Horizonte, 56: 472-479.

SAWADA, I. \& F. FunABaSHI. 1972. A new avian cestode, Metroliasthes coturnix sp. nov. from the intestine of a Japanese quail, with an avian cestode from a macaw. Japanese Journal of Parasitology, Tokyo, 21: 395-399.

SICK, H. 2001. Ornitologia brasileira. Rio de Janeiro, Nova Fronteira, 862p.

Uchida, A.; K. Uchida \& T. Sagawa. 1984. The first record of the cestode, Choanotaenia infundibulum (Dilepididae) in Japanese quails from Japan. Bulletin of the Azabu University of Veterinary Medicine, Fuchinobe, 5: 29-32.

WANG, P.Q. 1982. Notes on some digenetic trematodes of birds in Fujian Province. Wuyi Science Journal, Fuzhou, 2: 75-90.

Received in 15.III.2005; accepted in 23.IX.2005.

Revista Brasileira de Zoologia 22 (4): 836-838, dezembro 2005 